\title{
Microencapsulation of Hibiscus sabdariffa (Roselle) Extracts by Spray Drying Using Maltodextrin and Gum Arabic as Carriers
}

\author{
Sandro Cid-Ortega ${ }^{1,2}$ \& José Ángel Guerrero-Beltrán ${ }^{1}$ \\ ${ }^{1}$ Departamento de Ingeniería Química, Alimentos y Ambiental, Universidad de las Américas, Cholula, Puebla, \\ México \\ ${ }^{2}$ Programa Educativo de Ingeniería en Procesos Alimentarios, Universidad Tecnológica de Izúcar de Matamors, \\ Izúcar de Matamoros, Puebla, México \\ Correspondence: José Ángel Guerrero-Beltrán, Departamento de Ingeniería Química, Alimentos y Ambiental. \\ Universidad de las Américas, Puebla. Ex hacienda Sta. Catarina Mártir, Cholula, Puebla 72810, México. T Tel: \\ 52-222-229-2126. E-mail: angel.guerrero@udlap.mx
}

Received: June 6, 2020

Accepted: July 15, $2020 \quad$ Online Published: July 31, 2020

doi:10.5539/jfr.v9n5p53

URL: https://doi.org/10.5539/jfr.v9n5p53

\begin{abstract}
Microencapsulation by spray drying is one of the most common methods used to obtain food material powders. In this study, different gums (maltodextrin [MD], gum arabic [GA], and mixtures of MD:GA [60:40] at various concentrations $[0-10 \% \mathrm{w} / \mathrm{w}]$ ) were used to microencapsulate Hibiscus sabdariffa (Roselle) extracts by spray drying. The yield, physicochemical properties, and antioxidant characteristics (total monomeric anthocyanins [TMAs], total phenolic compounds [TPCs], and antioxidant capacity [AC]) of the microencapsulated Roselle powders $(\mathrm{RP})$ were evaluated. The highest RP yield $(73.3 \pm 3.3 \%)$ was obtained with the $3 \% \mathrm{MD}$ :GA blend. The red color $\left(a^{*}\right)$ average for all powders $(39.9 \pm 2.0)$ decreased as the gum concentration increased. The $3 \%$ MD:GA RP showed the highest amount of TMAs (539.19 $\pm 13.27 \mathrm{mg}$ cyaniding-3-glucoside equivalents/100 $\mathrm{g}$ ) and TPCs $(3,801.6 \pm 125.9 \mathrm{mg}$ of gallic acid equivalents $/ 100 \mathrm{~g}$ of powder). The highest $\mathrm{AC}$ was observed with a $5 \%$ GA RP $(1498.5 \pm 44.0 \mathrm{mg}$ of Trolox equivalents $/ 100 \mathrm{~g}$ of powder $)$.
\end{abstract}

Keywords: microencapsulation, spray drying, Hibiscus sabdariffa, Roselle, anthocyanins, phenolic compounds, antioxidant capacity

\section{Introduction}

Hibiscus sabdariffa is a plant in the Malvaceae family. It grows in tropical and subtropical regions and can have green or red calyces (Cissé et al., 2009). The red color of calyces reflects the high anthocyanin, mainly delphinidin-3-sambubioside (71.4\%) and cyanidin-3-sambubioside (26.6\%) content (Peng-Kong et al., 2002). These compounds are highly unstable and degrade easily, producing compounds with an undesirable color (browning). One of the main attributes of food quality is color and consumer acceptance depends greatly on color. Anthocyanins are colorful pigments from vegetable products; the stability of anthocyanins depends on various factors such as temperature, $\mathrm{pH}$, oxygen, light, enzymes, and metallic ions (Idham et al., 2012; Ersus et al., 2007).

One technique that has been used to maintain the stability of pigments such as anthocyanins is microencapsulation. Microencapsulation of food materials is used to reduce pigment degradation due to environmental factors such as oxygen, light, temperature, and prooxidant agents, to increase stability during processing, to control their release, or as a food additive (Santos and Meireles, 2010). Encapsulating agents include natural polymers and derivatives of these or lipids. The most common of these are gum arabic (GA), carrageenin, maltodextrins (MDs), cyclodextrins, dextrins, chitosan, gelatin, sodium caseinate, pregelatinizated starch, carboximethylcellulose, methylcellulose, hydroxypropyl methylcellulose, milk proteins (caseins and whey), lactose, corn syrup (Munin and Edwards-Lévy, 2011; Selim et al., 2008; Kolanowski et al., 2006; Vega and Roos, 2006), and mesquite gum (Ochoa-Velasco et al., 2017). The ideal substances for microencapsulation are soft and unflavored and have high solubility, emulsifying properties, and characteristics that promote drying. Furthermore, their concentrated solutions should have low viscosity to facilitate drying (Vega and Roos, 2006). MDs and GA are the encapsulating agents most commonly used with spray drying. MDs solubilize rapidly and have low viscosities at high concentrations; however, their emulsifying capacity is limited. MDs in the range of 
10-20 dextrose equivalents (DEs) are the most suitable for use as encapsulating agents. On the other hand, GA is a very efficient encapsulating agent; it is a polymer with $2 \%$ of its structural proteins lending excellent emulsifying properties. However, high concentrations of GA increase the viscosity of solutions (Gharsallaoui et al., 2007). Combinations of MDs with GA used with spray drying have been shown to produce good powders (Zhang, Mou, and Du, 2007; Lopez et al., 2009; Idham et al., 2012; Fazaeli et al., 2012).

Microencapsulation is a widely used process in the food, pharmaceutical, and cosmetics industries, as well as in agricultural, veterinary, medical, chemical, biotechnological, and biomedical fields. Spray drying is a widely used economical method for encapsulating food ingredients. Particle sizes of powders obtained by this method are generally in the range of $10-50 \mu \mathrm{m}$; however, this size may depend on the process conditions (Gharsallaoui et al., 2007). The main advantages of this process, besides its simplicity, are its suitability for use with heat-sensitive materials because the time required at high temperatures is very short (5-30 s) (Ochoa-Velasco et al., 2017), the equipment needed is readily available, options for encapsulating materials are many, the encapsulation process is efficient, the final product is stable, and there is the potential for continuous large scale production (Santos and Meireles, 2010). The parameters that have the most influence in the spray drying process are nozzle geometry, viscosity of the feeding solution, and the inlet and outlet air temperatures (Munin and Edwards-Lévy, 2011; Gharsallaoui et al., 2007). Commercially, this technique has been used to encapsulate numerous materials, including flavor agents, fats, oils, vitamins, minerals, microorganisms, enzymes, sweeteners, and colorants (Wijaya et al., 2011).

There is little research on spray drying of Roselle extracts (REs) to obtain powders. Some researchers have found that powders obtained by spray drying using encapsulating agents (mainly MDs) are more stable and have longer lasting antioxidant properties than those obtained without encapsulating agents (Langrish and Chiou, 2008a, 2008b; Farimin and Nordin, 2009; Ochoa-Velasco et al., 2017).

The aim of this work was to evaluate the use of an MD, GA, and combination of the two as encapsulating agents to obtain Roselle powders by spray drying.

\section{Materials and Method}

\subsection{Materials}

Red Creole Roselle calyces (long variety) were acquired from Chiautla de Tapia, Puebla, Mexico to produce extracts. Roselle calyces powder (RCP) was obtained using a stainless steel VeyCo MPV Mill Model 100 (Mexico). The mill has a mesh of $0.5 \mathrm{~mm}$.

\subsection{Methods}

\subsubsection{Average Particle Size}

Average particle size (APS) was determined using a Microtac S3500 Particle Size Analyzer (Microtac Inc., Largo, FL, USA) with a measuring range of $0.25-2800 \mu \mathrm{m}$. Approximately 30 and $60 \mathrm{mg}$ of spray-dried Roselle powders (RPs) and RCP were used, respectively, to assess particle size. The analysis was performed in triplicate. Particle size distributions, mean diameters of particles $\left(d_{50}\right)$, and cumulative weight curves were obtained for the different powders (O’Hagan et al., 2005).

\subsubsection{Concentrated RE}

$\mathrm{RE}$ was obtained with a 1:10 RCP:ethanol ratio $\left(20 \mathrm{~g}\right.$ of $\mathrm{RCP}+200 \mathrm{~mL}$ of $50 \%$ ethanol) at $50 \pm 0.2^{\circ} \mathrm{C}$ for 30 min using a Riossa M80T water bath (Rios Rocha S. A., Monterrey, Nuevo Leon, Mexico), based on a method described by Salazar-González, Vergara-Balderas, Ortega-Regules, and Guerrero-Beltrán (2012). RE was filtered through Whatman paper No. 4, and the liquid was obtained in flasks that were then covered with aluminum foil (Cid-Ortega and Guerrero-Beltrán, 2014). To obtain concentrated REs, alcohol was removed using a Büchi rotary evaporator RE 111 (Brinkmann Instruments Inc., Switzerland) at $45^{\circ} \mathrm{C}$ and $54 \mathrm{cmHg}$ for no more than 45 min (Selim et al., 2008). The concentrated RE was evaluated according to volume, weight, and physicochemical (total soluble solids [TSSs], density, viscosity) and antioxidant (total monomeric anthocyanins [TMAs], total phenolic compounds [TPCs], and antioxidant capacity [AC]) characteristics.

\subsubsection{Concentrated RE-gums}

A $3 \times 3$ factorial design with the type or blend of gum (GA, MD, and an MD:GA [60:40] blend) and their concentration $(3,5$, and $10 \% \mathrm{w} / \mathrm{w})$ was used (Idham et al., 2012). GA was acquired from Central de Drogas, S. A. de C.V. (Mexico State, Mexico). MD of 9-14 DEs was acquired from CP Ingredientes S. A. de C.V. (Guadalajara, Jalisco, Mexico). The gum or blend of gums was added to the RE concentrate and stirred for $15 \mathrm{~min}$ at room temperature $\left(22 \pm 2^{\circ} \mathrm{C}\right)$. Each RE-gum concentrate was placed in a 250-mL Erlenmeyer flask, covered with 
aluminum foil, and stored a $4{ }^{\circ} \mathrm{C}$ until spray drying. RE and RE-gum concentrates were analyzed for physicochemical (TSSs, density, viscosity) and antioxidant (TMAs, TPCs, and AC) characteristics.

\subsubsection{Spray Drying}

A mini spray dryer (Büchi B-290, Switzerland) with a two-fluid nozzle with an orifice $0.7 \mathrm{~mm}$ in diameter (particle diameter of 1-25 microns) was used for spray drying. The inlet and outlet air temperatures were 180.01 \pm 0.25 and $105.16 \pm 3.52^{\circ} \mathrm{C}$, respectively. Blends of RE-gum concentrates were fed into the dryer at a flow rate of $10 \mathrm{~mL} / \mathrm{min}$ (Andrade and Flores, 2004; Ochoa-Velasco et al., 2017). The aspirator power of the drying system was $100 \%$ (equivalent to an airflow of $35 \mathrm{~m}^{3} / \mathrm{h}$ ), and the spray drying airflow was maintained at $55 \mathrm{~mm}$ (equivalent to $670 \mathrm{~L} / \mathrm{h}$ with a pressure of $1.05 \mathrm{bar}$ ). Calibration curves were constructed (10-100\% pump power) to determine the percentage equivalent to $10 \mathrm{~mL} / \mathrm{min}$ for each mixture (38-41\%). RPs were weighed and placed in $100-\mathrm{mL}$ amber glass bottles, and these bottles were capped and stored at room temperature $\left(22 \pm 2^{\circ} \mathrm{C}\right)$ in a desiccator containing silica. Yield, productivity, physical characteristics (moisture content, water activity [aw], average diameter, bulk and tapped densities, and color), and antioxidant characteristics (TMAs, TPCs, and AC) of RPs were determined.

\subsubsection{Physical Properties of Extracts}

Total soluble solids (TSSs). TSSs were measured according to the 932.14C AOAC (1995) method using a handheld refractometer (Atago Co. LTD, Tokyo, Japan). To correct values for $20^{\circ} \mathrm{C}$, a standard set of tables were used (AOAC, 1995).

Density. Density was determined according to the 945.06 AOAC (1995) method and expressed in g per mL. Empty $\left(W_{l}\right)$, filled with distilled water $\left(W_{2}\right)$, and filled with sample $\left(W_{3}\right)$ pycnometer weights were determined, and the density at $25^{\circ} \mathrm{C}$ was calculated according to Eq. (1):

$$
\rho(g / m L)=\left[\frac{W_{2}-W_{1}}{W_{3}-W_{1}}\right] * \rho_{H_{2} O}^{25^{\circ} \mathrm{C}}
$$

where $\rho_{\mathrm{H}_{2} \mathrm{O}}^{25^{\circ} \mathrm{C}}(\mathrm{g} / \mathrm{mL})$ is the density of water at $25^{\circ} \mathrm{C}$.

Absolute viscosity $(\mu)$. A Cannon-Fenske capillary viscometer (Cannon Instrument Co., State College, PA, USA) was used to determine absolute viscosity. Kinematic viscosity was calculated by multiplying the time (s) of 6.6 $\mathrm{mL}$ of extract at $40^{\circ} \mathrm{C}$ flowing through the viscometer per the constant of the apparatus $\left(0.4754 \mathrm{~mm}^{2} / \mathrm{s}^{2}\right)$ at the same temperature. To obtain absolute viscosity, kinematic viscosity was multiplied by the density of the extract according to Eq. (2) (Cannon Instrument Co., 2000):

$$
\mu(c P)=\rho_{s} * v_{c}
$$

where $\mu$ is the absolute viscosity ( $\mathrm{cP}=\mathrm{mPa}), \rho_{s}$ is the density $(\mathrm{g} / \mathrm{mL})$, and $v_{c}$ is the kinematic viscosity $\left(\mathrm{mm}^{2} / \mathrm{s}\right.$ $=\mathrm{cSt}$ ) of an extract. The absolute viscosity at $25^{\circ} \mathrm{C}$ was calculated using Eq. (3) (Cannon Instrument Co., 2014):

$$
C=C_{o}\left[1-B\left(T_{t}-T_{f}\right)\right]
$$

where $C\left(0.4754 \mathrm{~mm}^{2} / \mathrm{s}^{2}\right)$ is the constant of the apparatus at $40^{\circ} \mathrm{C}, C_{o}\left(\mathrm{~mm}^{2} / \mathrm{s}^{2}\right)$ is the viscometer constant at the filling temperature, $\mathrm{B}\left(79 \times 10^{-6} /{ }^{\circ} \mathrm{C}\right)$ is the calibration temperature factor obtained from the calibration certificate for the viscometer, $T_{t}$ is the working temperature $\left(40^{\circ} \mathrm{C}\right)$, and $T_{f}$ is the filling temperature. Using the equation above, the constant $C_{o}$ was calculated and then, using the same equation, the constant $C$ was calculated at $25^{\circ} \mathrm{C}$.

\subsubsection{Antioxidant Properties}

Total monomeric anthocyanins (TMAs). TMAs were determined according to the method described by Lee et al. (2005). First, $0.5 \mathrm{~mL}$ or $100 \mathrm{mg}$ of extract or powder, respectively, were diluted with distilled water to reach 10 $\mathrm{mL}$ in a volumetric flask. The mixture was stirred for $5 \mathrm{~min}$ using a vortex at 2900-3000 rpm. One milliliter of each solution was diluted with buffer $\mathrm{pH} 1.0$ or $\mathrm{pH} 4.5$ to reach $5 \mathrm{~mL}$ in test tubes wrapped with aluminum foil. The blends were left for $30 \mathrm{~min}$ at room temperature $\left(23 \pm 2^{\circ} \mathrm{C}\right)$ in the dark. Then, absorbances in 4-mL glass cells were measured at 520 and $700 \mathrm{~nm}$ using a Cary $100 \mathrm{UV}$-Vis spectrophotometer (Varian Inc., Palo Alto, CA, USA). A blank with distilled water was used to correct these absorbances. Results were calculated as mg of cyanidin-3-glucoside equivalents per $100 \mathrm{~mL}$ of RE or per $100 \mathrm{~g}$ of powder using Eq. (4): 


$$
T M A=\frac{A * M W * D F}{\varepsilon * L} * 100
$$

where $T M A$ is the concentration of anthocyanins $(\mathrm{mg} / 100 \mathrm{~mL}$ or $\mathrm{mg} / 100 \mathrm{~g}), A=\left(\mathrm{A}_{520 \mathrm{~nm}}-\mathrm{A}_{700 \mathrm{~nm}}\right)_{\mathrm{pH}=1.0}-\left(\mathrm{A}_{520 \mathrm{~nm}}-\right.$ $\left.\mathrm{A}_{700 \mathrm{~nm}}\right)_{\mathrm{pH}=4.5}, M W$ is the molecular weight of cyanidin-3-glucoside (449.2 g/mole), $D F$ is the dilution factor, $L$ is the cell width $(1 \mathrm{~cm}), \varepsilon$ is the coefficient of molar extinction for cyanidin-3-glucoside $(26,900 \mathrm{~L} / \mathrm{mole}-\mathrm{cm})$, and 100 is the conversion factor for obtaining $\mathrm{mg} / 100 \mathrm{~mL}$ of $\mathrm{RE}$ or $\mathrm{mg} / 100 \mathrm{~g}$ of RP.

Total phenolic compounds (TPCS). TPCs were determined using the Phenol Folin and Ciocalteu method (Singleton and Rossi, 1965) with some modifications. Three milliliters of distilled water, $150 \mu \mathrm{L}$ of extract solution, or $100 \mu \mathrm{L}$ of powder solution (the same solutions prepared to determine TMAs), and $250 \mu \mathrm{L}$ of Folin and Ciocalteu reagent were placed in test tubes that were then covered with aluminum foil. Mixtures were stirred and left for a maximum of $8 \mathrm{~min}$ in the dark, and then $750 \mu \mathrm{L}$ of $20 \% \mathrm{Na}_{2} \mathrm{CO}_{3}$ was added and thoroughly mixed. Distilled water was added $(850$ or $900 \mu \mathrm{L})$ to reach $5 \mathrm{~mL}$, mixed thoroughly, and left for $2 \mathrm{~h}$ at room temperature $\left(23 \pm 2{ }^{\circ} \mathrm{C}\right)$ in the dark. Absorbances were measured at $765 \mathrm{~nm}$ using a Cary $100 \mathrm{UV}$-visible spectrophotometer (Varian Inc.). Various standard curves were constructed with different concentrations of gallic acid (0-0.066 mg; Sigma, St. Louis, MO, USA). The standard curve for extracts and powders is represented by the equation $\mathrm{A}=$ $18.810 \pm 1.463(1 / \mathrm{mg} \mathrm{GA}) * \mathrm{X}(\mathrm{mg} \mathrm{GA})+0.023 \pm 0.007\left(\mathrm{R}^{2}=0.998 \pm 0.001\right)$. The amount of TPCs was calculated as $\mathrm{mg}$ of gallic acid equivalents per $100 \mathrm{~mL}$ of RE or per $100 \mathrm{~g}$ of powder according to Eq. (5):

$$
T P C\left(\frac{m g}{100 m L}\right)=\left(\frac{A-b}{m}\right) * D F * 100
$$

where TPC is the total phenolic compounds content $(\mathrm{mg} / 100 \mathrm{~mL}$ or $\mathrm{mg} / 100 \mathrm{~g}), A$ is the absorbance of the sample, $b$ is the intercept, $m$ is the slope, and $D F$ is the dilution factor for the sample.

Antioxidant capacity (AC). The DPPH (1,1-diphenyl-2-picrylhydrazyl) method (Brand-Williams et al., 1995) was used with some modifications (Molyneux, 2004; Esmaeili et al., 2015). Two milliliters of extract solution or $100 \mu \mathrm{L}$ of powder solution (the same solutions prepared to determine TMAs) were diluted with ethanol (99.5\%) to reach $10 \mathrm{~mL}$ in a volumetric flask, stirred for 5 min using a vortex (2900-3000 rpm), and then filtered through Whatman paper No. 4. One milliliter of filtrate was placed in a test tube containing $1 \mathrm{~mL}$ of ethanol (99.5\%) and $2 \mathrm{~mL}$ of DPPH solution $(7.99 \pm 0.24 \mathrm{mg}$ in $200 \mathrm{~mL}$ of $99.5 \%$ ethanol). The solutions were thoroughly mixed and left for $45 \mathrm{~min}$ at room temperature $\left(21.6 \pm 3.3^{\circ} \mathrm{C}\right)$ in the dark. Absorbances were measured at $517 \mathrm{~nm}$ using a Cary 100 UV-Vis spectrophotometer (Varian Inc.). The AC of each solution was calculated using Eq. (6):

$$
I(\%)=\frac{A c-A s}{A c} * 100
$$

where $I$ is the percent of inhibition, $A s$ is the absorbance of the sample and $A c$ is the absorbance of the control. Standard curves were prepared at various concentrations $(0,0.008-0.030 \mathrm{mg})$ of Trolox (6-hydroxy-2, 5, 7, 8 tetrametilcromo-2 carboxylic acid 97\%). The standard curves for extracts and powders are represented by the equation $\mathrm{I}(\%)=3272.18 \pm 220.83(1 / \mathrm{mg} \mathrm{TE}) * \mathrm{X}(\mathrm{mg} \mathrm{TE})+0.70 \pm 4.06\left(\mathrm{R}^{2}=0.978 \pm 0.014\right)$, and $\mathrm{I}(\%)=$ $3269.52 \pm 251.15(1 / \mathrm{mg}$ TE$) * X(\mathrm{mg} \mathrm{TE})+4.78 \pm 4.37\left(\mathrm{R}^{2}=0.964 \pm 0.026\right)$, respectively. Results, calculated according to Eq. (7), were expressed as milligrams of TEs per $100 \mathrm{~mL}$ of RE or $100 \mathrm{~g}$ of powder.

$$
A C\left(\frac{m g}{100 m L}\right)=\left(\frac{A-b}{m}\right) * D F * 100
$$

where $A C$ is the antioxidant capacity $(\mathrm{mg} / 100 \mathrm{~mL}$ or $\mathrm{mg} / 100 \mathrm{~g}), A$ is the absorbance of the sample, $b$ is the intercept, $m$ is the slope, and $D F$ is the dilution factor of the sample.

\subsubsection{Physicochemical Properties of Powders}

Yield (Y). Yield was calculated based on the amount of TSSs in the encapsulated extract and the amount of powder obtained (Fazaeli et al., 2012) according to Eq. (8):

$$
Y(\%)=\frac{\text { Amount of powder }}{\text { Amount of } T S S} * 100
$$

Moisture content. Moisture content was measured according to the 934.06 AOAC (2000) method. A Cole-Parmer (Chicago, IL, USA) vacuum oven was used to dry samples for $8 \mathrm{~h}$ at $70 \pm 1^{\circ} \mathrm{C}$ and a vacuum pressure of 200 $220 \mathrm{mmHg}$. Moisture content was calculated as a percentage.

Water activity $\left(a_{w}\right)$. Water activity was measured using an AQUA-LAB hygrometer model 3TE (Decagon 
Devices Inc., Pullman, WA, USA). The temperature at the time of measurement was $25.10 \pm 0.06^{\circ} \mathrm{C}$.

Bulk density. Bulk density was measured according to the method described by Jumah et al. (2000). One gram of powder was weighed in a 10-mL graduated cylinder. The cylinder was gently tapped 10 times on a polystyrene mat from a height of $15 \mathrm{~cm}$. Bulk density $\left(\rho_{a}\right)$ was calculated according to Eq. (9):

$$
\rho_{a}(g / m L)=\frac{W}{V_{a}}
$$

where $W$ is the weight of powder $(\mathrm{g})$ and $V a$ is the apparent volume $(\mathrm{mL})$ occupied by the powder in the cylinder after tapping.

Tapped density. Tapped density was measured according to the Mexican Official Norm number NOM-104-STPS-2001 (NOM, 2001) with some modifications. One gram of powder was weighed in a 10-mL graduated cylinder with a rubber stopper. The cylinder was subjected to a manual vibration process so that the sample were shaken from bottom to top for $8 \mathrm{~min}$ (estimated time at maximum volume). The tapped density $\left(\rho_{c}\right)$ was calculated according to Eq. (10):

$$
\rho_{\mathrm{c}}(\mathrm{g} / \mathrm{mL})=\frac{\mathrm{W}}{\mathrm{Vc}}
$$

where $\mathrm{W}$ is the weight of powder $(\mathrm{g})$ and $\mathrm{Vc}$ is the compacted volume $(\mathrm{mL})$ occupied by the powder in the cylinder after tapping.

Color. A Colorgard system 05 colorimeter (BYK-Gardner Inc., Silver Spring, MD, USA) was used to determine the color of powders and solutions. For powders, the color parameters were obtained in reflectance mode. A plate with a light gap $1.9 \mathrm{~cm}$ in diameter and external diameter of $2.65 \mathrm{~cm}$ was used. Samples were placed in weighing bottles for color determination. For solutions, a solution of $10 \mathrm{mg}$ of powder/mL of distilled water was prepared, and color parameters were determined in transmittance mode using a 3-mL quartz cell (Konica Minolta Sensing, Inc., Kyoto, Japan) (Ochoa-Velasco et al., 2017; Silva et al., 2013). Color parameters of powders and solutions were obtained using the CIEL*a*b* scale: $L^{*}$ (lightness, 0-100), $a^{*}$ (green to red) and $b^{*}$ (blue to yellow). From these data, purity (color saturation, $\left.C=\left[a^{* 2}+b^{* 2}\right]^{1 / 2}\right)$ and hue $\left(H=\tan ^{-1}\left[b^{*} / a^{*}\right]\right)$ were calculated.

\subsubsection{Statistical Analysis}

Data were subjected to analysis of variance (ANOVA) testing using MINITAB software version 14.1. Multivariate analysis and Tukey's multiple comparison tests were used to compare differences between means. Values shown are average values. A value of 0.05 was considered significant for differences between means of treatments.

\section{Results and Discussion}

\subsection{Antioxidant Characteristics of RE Concentrates}

Table 1 shows the characteristics of RE concentrates. Roselle extracts had average initial volumes, weights, and TSSs of 73.10 $\pm 3.09,7.83 \pm 4.38$, and 15.04 \pm 0.80 , respectively, and average TMAs, TPCs, and ACs of $84.10 \pm$ 4.77, $629.97 \pm 30.25$, and $257.00 \pm 10.68$, respectively (Table 2). Statistically significant differences in TMA contents were observed $(\mathrm{p}>0.05)$ for all extracts $(70.65-91.26 \mathrm{mg} / 100 \mathrm{~mL})$. Extracts with 3 and $5 \%$ GA and 3 and $5 \% \mathrm{MD}$ added $(462.43 \pm 22.41,457.66 \pm 30.48,466.53 \pm 17.18$, and $456.53 \pm 28.07 \mathrm{mg} / 100 \mathrm{~mL}$ extract, respectively) showed less ( $\mathrm{p} \leq 0.05$ ) TPCs than those in RE alone. Extracts with $3 \%$ GA and $10 \%$ MD added $(227.32 \pm 5.12$ and $220.99 \pm 15.71 \mathrm{mg} / 100 \mathrm{~mL}$ extract, respectively) showed significantly lower ACs than $\mathrm{RE}$ alone. Significant differences $(\mathrm{p} \leq 0.05)$ in ACs for all RE-gum concentrates. 
Table 1. Roselle extract concentrate and gum required for each Roselle extract-gum concentrate

\begin{tabular}{llllll}
\hline Gum & Concentration $(\% \mathrm{w} / \mathrm{w})$ & Gum $(\mathrm{g})$ & Extract $(\mathrm{mL})$ & Extract $(\mathrm{g})$ & TSSs $^{1}(\%)$ \\
\hline RE & 0 & - & $73.10 \pm 3.09$ & $73.83 \pm 4.38$ & $15.04 \pm 0.80$ \\
$\mathrm{GA}$ & 3 & $2.77 \pm 0.19$ & $88.83 \pm 6.53$ & $89.43 \pm 6.29$ & $16.78 \pm 0.03$ \\
& 5 & $4.35 \pm 0.63$ & $82.00 \pm 12.49$ & $82.67 \pm 12.02$ & $17.54 \pm 0.48$ \\
& 10 & $9.22 \pm 0.64$ & $82.17 \pm 6.05$ & $82.97 \pm 5.75$ & $17.18 \pm 0.29$ \\
$\mathrm{MD}$ & 3 & $2.63 \pm 0.07$ & $83.34 \pm 2.36$ & $83.84 \pm 2.37$ & $17.15 \pm 0.16$ \\
& 5 & $4.64 \pm 0.28$ & $85.21 \pm 5.03$ & $85.21 \pm 5.03$ & $16.91 \pm 0.81$ \\
& 10 & $9.60 \pm 0.70$ & $84.33 \pm 6.81$ & $85.36 \pm 6.32$ & $17.06 \pm 0.46$ \\
MD:GA & 3 & $2.18 \pm 0.18$ & $67.43 \pm 6.02$ & $69.75 \pm 6.02$ & $14.39 \pm 0.37$ \\
& 5 & $3.97 \pm 0.06$ & $72.51 \pm 0.87$ & $74.77 \pm 0.93$ & $14.34 \pm 0.11$ \\
& 10 & $8.72 \pm 0.49$ & $76.54 \pm 5.24$ & $77.53 \pm 4.95$ & $17.31 \pm 0.43$ \\
\hline
\end{tabular}

${ }^{1} \mathrm{TSS}$ : total soluble solids $\left(\right.$ at $\left.20^{\circ} \mathrm{C}\right)$ in extracts without gum. RE, Roselle extract; GA, gum arabic; MD, maltodextrin.

Table 2. Antioxidant characteristics for Roselle extract concentrates ${ }^{\mathrm{a}}$

\begin{tabular}{lllll}
\hline Gum & Concentration & $\mathrm{TMA}^{1}$ & \multicolumn{1}{l}{$\mathrm{TPC}^{2}$} & $\mathrm{AC}^{3}$ \\
\hline & $(\% \mathrm{w} / \mathrm{w})$ & & $(\mathrm{mg} / 100 \mathrm{~mL})$ & \\
\hline $\mathrm{RE}$ & 0 & $84.10 \pm 4.77 \mathrm{abc}$ & $624.97 \pm 30.25 \mathrm{a}$ & $257.87 \pm 10.68 \mathrm{abc}$ \\
$\mathrm{GA}$ & 3 & $76.11 \pm 3.31 \mathrm{ac}$ & $462.43 \pm 22.41 \mathrm{c}$ & $227.32 \pm 5.12 \mathrm{bc}$ \\
& 5 & $82.07 \pm 10.98 \mathrm{abc}$ & $457.66 \pm 30.48 \mathrm{c}$ & $278.59 \pm 41.77 \mathrm{ab}$ \\
& 10 & $86.04 \pm 7.69 \mathrm{ab}$ & $491.32 \pm 19.18 \mathrm{c}$ & $235.26 \pm 15.01 \mathrm{abc}$ \\
$\mathrm{MD}$ & 3 & $74.11 \pm 3.78 \mathrm{bc}$ & $466.53 \pm 17.18 \mathrm{c}$ & $251.42 \pm 4.42 \mathrm{abc}$ \\
& 5 & $70.65 \pm 3.37 \mathrm{c}$ & $456.53 \pm 28.07 \mathrm{c}$ & $268.98 \pm 10.47 \mathrm{abc}$ \\
& 10 & $76.53 \pm 1.91 \mathrm{abc}$ & $499.92 \pm 13.04 \mathrm{c}$ & $220.99 \pm 15.71 \mathrm{c}$ \\
MD:GA & 3 & $90.95 \pm 0.22 \mathrm{a}$ & $617.62 \pm 28.86 \mathrm{a}$ & $281.15 \pm 25.60 \mathrm{a}$ \\
& 5 & $91.26 \pm 1.50 \mathrm{a}$ & $519.11 \pm 9.12 \mathrm{abc}$ & $263.80 \pm 3.49 \mathrm{abc}$ \\
& 10 & $83.50 \pm 4.02 \mathrm{abc}$ & $590.76 \pm 43.98 \mathrm{ab}$ & $251.72 \pm 13.90 \mathrm{abc}$ \\
\hline
\end{tabular}

${ }^{a}$ Different letters in the same column indicate significant differences $(\mathrm{p} \leq 0.05)$ between values. ${ }^{1}$ TMAs: total monomeric anthocyanins (cyanidin-3-glucoside equivalents). ${ }^{2}$ TPCs: total phenolic compounds (gallic acid equivalents). ${ }^{3} \mathrm{AC}$ : antioxidant capacity (Trolox equivalents). RE, Roselle extract; GA, gum arabic; MD, maltodextrin.

\subsection{RE-gum Concentrates}

\subsubsection{Physical Properties}

TSSs $\left({ }^{\circ} \mathrm{Bx}\right)$. Significant differences $(\mathrm{p} \leq 0.05)$ were observed between average TSS contents (Table 3$)$ for REs with GA, MD, or MD:GA added. The TSS content in REs was $15.04 \pm 0.80$. An increase of gums in REs increased TSS content (Table 3).

Table 3. Physical characteristics of Roselle extract concentrates ${ }^{\mathrm{a}}$

\begin{tabular}{lllll}
\hline Gum & Concentration $(\% \mathrm{w} / \mathrm{w})$ & TSSs $\left({ }^{\circ} \mathrm{Bx}\right)$ & Density $(\mathrm{g} / \mathrm{mL})$ & Viscosity $(\mathrm{mPa} \mathrm{s})^{1}$ \\
\hline $\mathrm{RE}$ & 0 & $15.04 \pm 0.80 \mathrm{e}$ & $1.03 \pm 0.01 \mathrm{ab}$ & $1.66 \pm 0.01 \mathrm{~g}$ \\
$\mathrm{GA}$ & 3 & $19.03 \pm 0.19 \mathrm{c}$ & $1.02 \pm 0.01 \mathrm{~b}$ & $2.79 \pm 0.05 \mathrm{fd}$ \\
& 5 & $20.86 \pm 0.48 \mathrm{~b}$ & $1.03 \pm 0.02 \mathrm{ab}$ & $3.68 \pm 0.01 \mathrm{c}$ \\
& 10 & $24.14 \pm 0.17 \mathrm{a}$ & $1.05 \pm 0.01 \mathrm{ab}$ & $8.44 \pm 0.1 \mathrm{a}$ \\
$\mathrm{MD}$ & 3 & $19.53 \pm 0.22 \mathrm{bc}$ & $1.02 \pm 0.01 \mathrm{~b}$ & $2.07 \pm 0.02 \mathrm{f}$ \\
& 5 & $20.73 \pm 0.39 \mathrm{~b}$ & $1.03 \pm 0.01 \mathrm{ab}$ & $2.29 \pm 0.07 \mathrm{e}$ \\
& 10 & $24.54 \pm 0.08 \mathrm{a}$ & $1.05 \pm 0.01 \mathrm{ab}$ & $2.99 \pm 0.07 \mathrm{~d}$ \\
MD:GA & 3 & $17.03 \pm 0.77 \mathrm{~d}$ & $1.05 \pm 0.01 \mathrm{ab}$ & $1.94 \pm 0.01 \mathrm{f}$ \\
& 5 & $18.73 \pm 0.59 \mathrm{c}$ & $1.05 \pm 0.00 \mathrm{ab}$ & $2.33 \pm 0.04 \mathrm{e}$ \\
& 10 & $24.90 \pm 0.23 \mathrm{a}$ & $1.06 \pm 0.01 \mathrm{a}$ & $4.39 \pm 0.09 \mathrm{~b}$ \\
\hline
\end{tabular}

${ }^{\mathrm{a}}$ Different letters in the same column indicate significant differences $(\mathrm{p} \leq 0.05)$ between values. ${ }^{1}$ Viscosity at $25^{\circ}$

C. TSSs, total soluble solids; RE, Roselle extract; GA, gum arabic; MD, maltodextrin. 
Density. Densities of RE-gum concentrates (Table 3) showed significant differences $(\mathrm{p} \leq 0.05$ ) among types and concentrations of gum. Extracts with the MD:GA blend added were denser $(1.06 \pm 0.01 \mathrm{~g} / \mathrm{mL})$ than extracts without gum (RE) or with GA and MD (1.03 $\pm 0.01,1.04 \pm 0.02$, and $1.03 \pm 0.01 \mathrm{~g} / \mathrm{mL}$, respectively). Densities of RE-gum concentrates with the three concentrations of gums also showed significant differences ( $\mathrm{p} \leq$ $0.05)$.

Viscosity. Viscosities of RE-gum concentrates are shown in Table 3. The viscosity of RE-gum concentrates increased as gum concentration increased $(1.66 \pm 0.01,2.26 \pm 0.40,277 \pm 0.69$, and $5.27 \pm 2.45 \mathrm{mPa}$ s, for $0,3,5$, and $10 \%$ gums, respectively). Extracts with $10 \%$ GA showed the highest viscosity, perhaps because GA has the ability to form gels due to its protein contents (Lopez et al., 2009). Significant differences ( $p \leq 0.05)$ in RE-gum concentrate viscosities were observed among concentrations and types of gum. Viscosity and TSS content are important for spray drying because low viscosities along with high TSS content results in better flow during atomization and higher yields (Lopez et al., 2009). Therefore, a positive correlation between viscosity and TSS content was observed with each treatment: GA $\left(\mathrm{R}^{2}=0.938\right), \mathrm{MD}\left(\mathrm{R}^{2}=0.988\right)$, and MD:GA $\left(\mathrm{R}^{2}=0.980\right)$.

\subsection{Roselle Powders (Rps)}

\subsubsection{Granulometry of RPs}

Figure 1 shows particle size distribution and cumulative percentages of RPs. The average diameter $\left(d_{50}\right)$ of particles was $221.03 \pm 3.97 \mathrm{~mm}$ and the moisture content was $6.45 \pm 0.43 \%$.

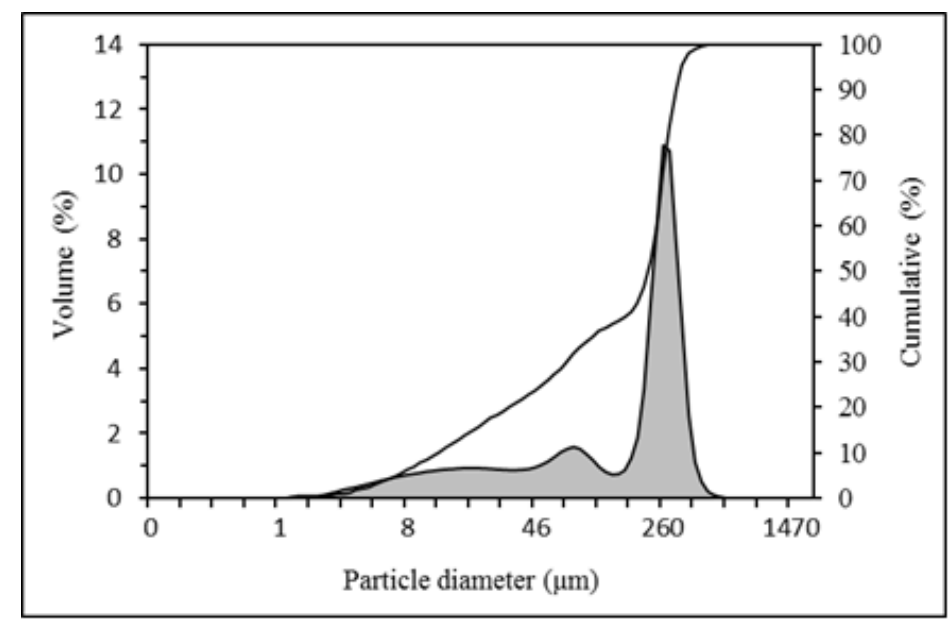

Figure 1. Particle size distribution of Roselle calyces powders

\subsubsection{Yield}

The yield for powder without gum was $58.19 \pm 5.06 \mathrm{~cd} \%$. The yields for powders with GA were $59.78 \pm 2.47 \mathrm{~cd}$, $65.18 \pm 5.25 \mathrm{bc}$, and $68.77 \pm 2.22 \mathrm{ab} \%$ with 3,5 , and $10 \%$ gums, respectively. The yields for powders with MD were $56.46 \pm 0.97 \mathrm{~d}, 59.81 \pm 1.49 \mathrm{~cd}, 72.07 \pm 2.12 \mathrm{ab} \%$ with 3,5 , and $10 \%$ gums, respectively. The yields for powders with MD:GA were $76.38 \pm 3.24 \mathrm{a}, 72.75 \pm 1.16 \mathrm{ab}$, and $70.79 \pm 2.60 \mathrm{ab} \%$ with 3,5 , and $10 \%$ gums, respectively. Regarding gum type, MD:GA RP showed the highest yield $(73.3 \pm 3.3 \%)$, and the RE and GA and MD RPs showed similar ( $p>0.05$ ) lower yields of $58.19 \pm 5.06,59.78 \pm 2.47$, and $59.81 \pm 1.49 \%$, respectively. Significant differences $(\mathrm{p} \leq 0.05)$ in yields were observed with 3,5 , and $10 \%$ gums $(64.2 \pm 9.5,65.9 \pm 6.3$, and $70.5 \pm 2.5 \%$, respectively). The control RP (of RE) showed a low yield ( $\leq 0.05$ ). Ochoa-Velasco et al. 2017) obtained an average yield of $73.7 \pm 1.5 \%$ for RPs microencapsulated by spray drying using mesquite gum at different concentrations $(1,2,3,4$, and $5 \% \mathrm{w} / \mathrm{v})$.

\subsubsection{Physicochemical Characteristics}

Moisture content. In general, RPs with the highest ( $p>0.05$ ) moisture contents were the following: $3.34 \pm 0.30$ and $3.29 \pm 0.27 \%$ for 3 and 5\% MD:GA, respectively; $3.29 \pm 0.27$ for RE; and $3.09 \pm 0.24$ and $2.29 \pm 0.15 \%$ for 10 and 3\% GA, respectively (Table 4). No significant differences $(\mathrm{p}>0.05)$ were observed in moisture contents with gum concentrations of $0,3,5$, and $10 \%(3.29 \pm 0.27,2.68 \pm 0.57,2.48 \pm 0.68$, and $2.60 \pm 0.41 \%$, respectively). Gonzales-Palomares et al. (2009) reported a moisture content of $4 \%$ in spray-dried powders using inlet and outlet temperatures of 180 and $80^{\circ} \mathrm{C}$, respectively, for control REs, which is similar to values obtained 
in this study (3.29 $\pm 0.27 \%)$. Likewise, Ochoa-Velasco et al. (2017) reported an average moisture content in spray-dried microencapsulated powders from REs using mesquite gum as an encapsulating agent at different concentrations $(1,2,3,4$, and $5 \% \mathrm{w} / \mathrm{v})$ of $2.29 \pm 0.45 \%$. This value is similar to the average moisture content $(2.59 \pm 0.55 \%)$ in RPs with different gums obtained in this study.

Table 4. Effect of gum type and concentration on the physicochemical properties of Roselle powders ${ }^{\mathrm{a}}$

\begin{tabular}{lllllll}
\hline $\begin{array}{l}\text { Gum } \\
\text { type }\end{array}$ & $\begin{array}{l}\text { GC }(\% \\
w / w)\end{array}$ & $\begin{array}{l}\text { Moisture } \\
(\%)\end{array}$ & $\begin{array}{l}a_{w} \\
(\text { at } \\
\left.25.1 \pm 0.06^{\circ} \mathrm{C}\right)\end{array}$ & $\begin{array}{l}\text { Average } \\
\text { diameter } \\
d_{50}(\mu \mathrm{m})\end{array}$ & $\begin{array}{l}\text { Bulk density } \\
(\mathrm{g} / \mathrm{mL})\end{array}$ & $\begin{array}{l}\text { Tap density } \\
(\mathrm{g} / \mathrm{mL})\end{array}$ \\
\hline $\mathrm{RE}$ & 0 & $3.29 \pm 0.27 \mathrm{a}$ & $0.183 \pm 0.012 \mathrm{def}$ & $12.16 \pm 1.01 \mathrm{~cd}$ & $0.380 \pm 0.020 \mathrm{a}$ & $0.483 \pm 0.021 \mathrm{~b}$ \\
$\mathrm{GA}$ & 3 & $2.59 \pm 0.15 \mathrm{bc}$ & $0.167 \pm 0.012 \mathrm{ef}$ & $9.69 \pm 0.59 \mathrm{abe}$ & $0.220 \pm 0.010 \mathrm{c}$ & $0.303 \pm 0.006 \mathrm{~b}$ \\
& 5 & $2.36 \pm 0.30 \mathrm{bcd}$ & $0.210 \pm 0.010 \mathrm{bcd}$ & $12.15 \pm 0.20 \mathrm{~cd}$ & $0.150 \pm 0.010 \mathrm{~d}$ & $0.233 \pm 0.015 \mathrm{e}$ \\
& 10 & $3.09 \pm 0.24 \mathrm{ab}$ & $0.247 \pm 0.006 \mathrm{a}$ & $14.92 \pm 0.25 \mathrm{ab}$ & $0.153 \pm 0.012 \mathrm{~d}$ & $0.250 \pm 0.017 \mathrm{e}$ \\
$\mathrm{MD}$ & 3 & $2.12 \pm 0.19 \mathrm{~cd}$ & $0.153 \pm 0.015 \mathrm{f}$ & $9.05 \pm 0.49 \mathrm{c}$ & $0.240 \pm 0.010 \mathrm{c}$ & $0.307 \pm 0.015 \mathrm{~b}$ \\
& 5 & $1.79 \pm 0.18 \mathrm{fd}$ & $0.173 \pm 0.006 \mathrm{ef}$ & $9.69 \pm 0.54 \mathrm{de}$ & $0.163 \pm 0.012 \mathrm{~b}$ & $0.233 \pm 0.021 \mathrm{e}$ \\
& 10 & $2.48 \pm 0.16 \mathrm{bc}$ & $0.163 \pm 0.015 \mathrm{f}$ & $13.93 \pm 0.51 \mathrm{abc}$ & $0.110 \pm 0.000 \mathrm{e}$ & $0.160 \pm 0.000 \mathrm{f}$ \\
$\mathrm{MD}: G A$ & 3 & $3.34 \pm 0.30 \mathrm{a}$ & $0.200 \pm 0.020 \mathrm{cde}$ & $9.12 \pm 0.17 \mathrm{e}$ & $0.353 \pm 0.021 \mathrm{a}$ & $0.540 \pm 0.035 \mathrm{a}$ \\
& 5 & $3.29 \pm 0.12 \mathrm{a}$ & $0.230 \pm 0.010 \mathrm{abc}$ & $12.42 \pm 1.53 \mathrm{bc}$ & $0.300 \pm 0.010 \mathrm{~b}$ & $0.370 \pm 0.010 \mathrm{c}$ \\
& 10 & $2.23 \pm 0.08 \mathrm{~cd}$ & $0.240 \pm 0.010 \mathrm{ab}$ & $16.20 \pm 2.02 \mathrm{a}$ & $0.097 \pm 0.012 \mathrm{e}$ & $0.133 \pm 0.015 \mathrm{f}$ \\
\hline
\end{tabular}

${ }^{a}$ Different letters in the same column indicate significant differences $(\mathrm{p} \leq 0.05)$ between values. GC, gum concentration; RE, Roselle extract; GA, gum arabic; MD, maltodextrin.

Water activity $\left(a_{w}\right)$. The stability of many foods depends on water activity (Fennema, 1985). High $a_{w}$ indicates high free water content and thus low food stability. Table 4 shows low $a_{w s}$ for all RPs. Average $a_{w s}$ for RPs with $\mathrm{MD}, \mathrm{GA}$, and MD:GA were $0.163 \pm 0.014,0.208 \pm 0.036$, and $0.223 \pm 0.022$, respectively. Significant differences $(\mathrm{p} \leq 0.05)$ were observed among types and concentrations of gums. The highest values were observed with $10 \%$ GA.

Average diameter $\left(d_{50}\right)$. Significant differences were observed between mean diameters of RE, GA, MD, and MD:GA RPs $(12.16 \pm 1.01,12.25 \pm 2.29,10.89 \pm 2.34$, and $12.58 \pm 3.32 \mu \mathrm{m}$, respectively (Table 4$)$. Diameters increased significantly $\left(0.5 \pm 9.29,11.42 \pm 1.54\right.$, and $\left.15.35 \pm 2.33 \mu \mathrm{m} ; \mathrm{R}^{2}=0.990\right)$ as gum concentrations increased from 3 to $10 \%$. The $d_{50}$ of RE RP $(12.16 \pm 1.01 \mu \mathrm{m})$ was similar ( $\left.\mathrm{p}>0.05\right)$ to those of 3 and $5 \%$ RPs and lower $(\mathrm{p} \leq 0.05)$ than that for $10 \%$ RPs. Particle sizes showed a unimodal distribution for RE, MD (Figure 2a), and GA RPs and a bimodal distribution for MD:GA RP (Figure 2b). Therefore, GA and MD RP particle sizes were more homogeneous and MD:GA RPs were more heterogeneous. This distribution could be attributed to agglomeration, which causes larger particles to form (Tonon et al., 2011). Figure 3 shows the TMA content for all encapsulated powders. An increase in $d_{50}$ was observed with a decrease in anthocyanin content. This behavior was very similar to what was observed for TPCs.

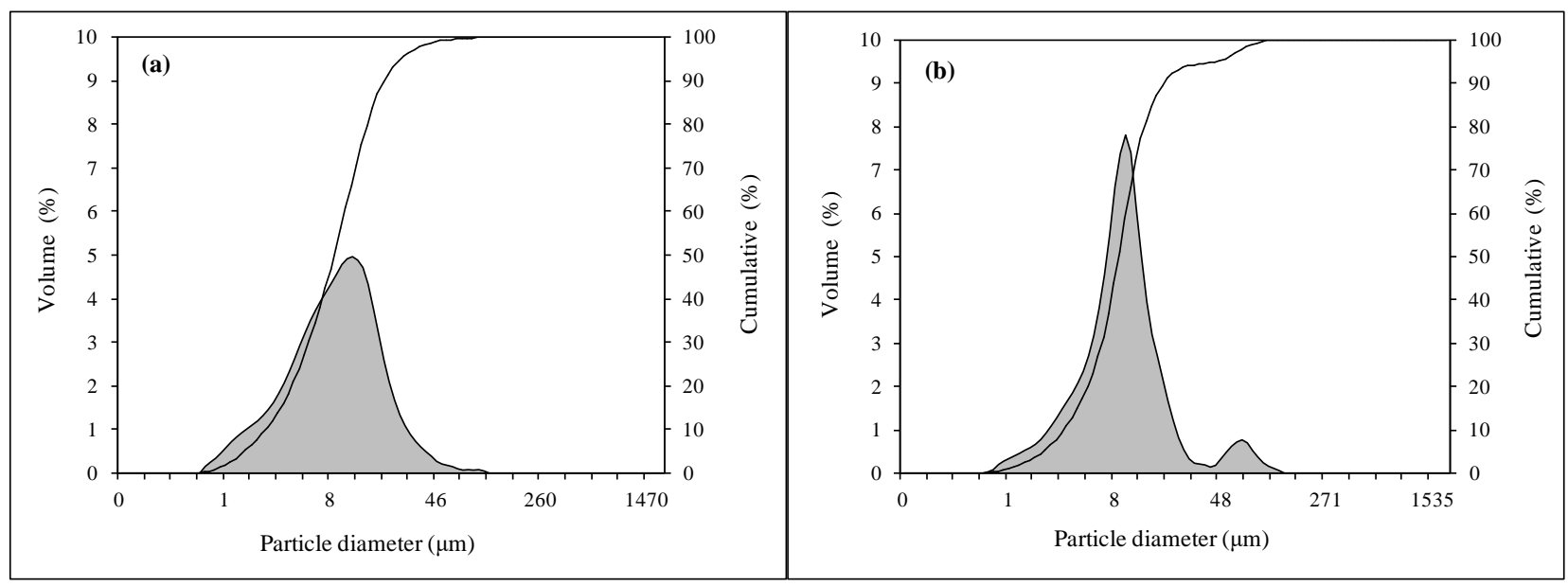

Figure 2. Particle size distribution of Roselle calyces, powders with 3\% maltodextrin (MD) (a) and 3\% maltodextrin:gum arabic (MD:GA) (b) 


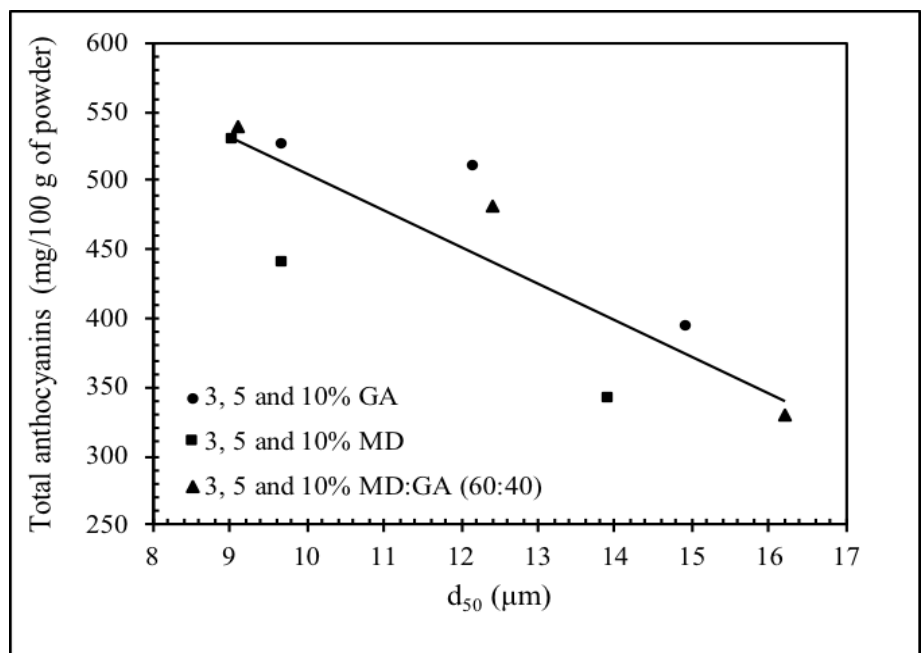

Figure 3. Correlation between total monomeric anthocyanin content and average diameter $\left(d_{50}\right)$ of particles in microencapsulated Roselle calyces powders with gum arabic (GA) and maltodextrin (MD)

Bulk density. Significant differences $(\mathrm{p} \leq 0.05)$ were observed between bulk densities of RPs with different gum types (Table 4). RE RPs showed a higher average bulk density $(0.380 \pm 0.020 \mathrm{~g} / \mathrm{mL})$ than RPs with GA $(0.174 \pm$ $0.035 \mathrm{~g} / \mathrm{mL}), \mathrm{MD}(0.171 \pm 0.057 \mathrm{~g} / \mathrm{mL})$, or MD:GA $(0.250 \pm 0.118 \mathrm{~g} / \mathrm{mL})$. As the concentration of gums increased, bulk densities of RPs decreased ( $\mathrm{p} \leq 0.05$ ): average densities of $0.271 \pm 0.064,0.204 \pm 0.072$, and $0.120 \pm 0.027 \mathrm{~g} / \mathrm{mL}$ were observed for 3, 5, and $10 \%$ gums, respectively. The highest bulk density was observed for RE $(0.380 \pm 0.020 \mathrm{~g} / \mathrm{mL})$ and for RPs with $3 \%$ MD:GA $(0.353 \pm 0.021 \mathrm{~g} / \mathrm{mL})$.

Tapped density. Table 4 shows the tapped densities of RPs. Tapped densities showed trends that were similar to those of bulk densities; however, because the RPs were tapped, all densities were higher.

\subsubsection{Color of Powders}

Lightness $\left(L^{*}\right)$. Significant differences were observed between RPs based on type and concentration of gums (Table 5). RE RPs $(41.15 \pm 1.00)$ were darker than those with GA $(55.76 \pm 1.90)$, MD $(57.14 \pm 3.97)$, and MD:GA (52.42 \pm 5.22$)$. Lightness of RPs increased with increasing gum concentration, with lightness measures of $41.15 \pm 1.00,51.51 \pm 3.18,54.36 \pm 3.03$, and $59.45 \pm 2.07$ for $0,3,5$, and $10 \%$ gums, respectively. Ochoa-Velasco et al. (2017) reported an average lightness value of $40.3 \pm 0.71$ for microencapsulated RPs obtained by spray drying using mesquite gum at different concentrations $(1,2,3,4$, and $5 \% \mathrm{w} / \mathrm{v})$; however, no significant differences were observed with the different microencapsulated powders. The authors concluded that gum concentration did not have a significant effect on all color properties. Idham et al. (2012) reported color parameters of RPs with the same gums used in this study, but they purified anthocyanins before they were mixed with the carrier for spray drying. They obtained $L^{*}, a^{*}$, and $b^{*}$ values of 44.9, 30.3, and -6.3 for RPs with GA; 39.3, 43.1, and -0.8 for RPs with MD; and 45.9, 34.8, and -4.3 for RPs with MD:GA. Gums were added to the extracts to reach a concentration of $20 \%$. The mixtures were fed into the spray dryer at a flow rate of $9.5 \%$ with inlet and outlet temperatures of 150 and $110^{\circ} \mathrm{C}$, respectively. 
Table 5. Effect of gum type and concentration on the color properties of spray-dried powders and powders in solution $^{\mathrm{a}}$

\begin{tabular}{|c|c|c|c|c|c|c|}
\hline Gum type & $\mathrm{GC}(\% \mathrm{w} / \mathrm{w})$ & $L^{*}$ & $a^{*}$ & $b^{*}$ & $H\left(^{\circ}\right)$ & $C$ \\
\hline \multicolumn{7}{|l|}{ Powder } \\
\hline $\mathrm{RE}$ & 0 & $41.15 \pm 1.01 \mathrm{~h}$ & $42.68 \pm 0.26 a$ & $16.31 \pm 0.25 \mathrm{a}$ & $20.92 \pm 0.40 \mathrm{a}$ & $45.69 \pm 0.17 \mathrm{a}$ \\
\hline \multirow[t]{3}{*}{ GA } & 3 & $54.25 \pm 0.94 \mathrm{de}$ & $40.66 \pm 0.33 b c$ & $11.17 \pm 0.41 \mathrm{dcd}$ & $15.36 \pm 0.46 b c$ & $42.17 \pm 0.40 \mathrm{~cd}$ \\
\hline & 5 & $55.59 \pm 2.33 \mathrm{cde}$ & $39.77 \pm 0.95 \mathrm{~cd}$ & $10.31 \pm 0.64 d$ & $14.53 \pm 0.54 c$ & $41.08 \pm 1.08 \mathrm{be}$ \\
\hline & 10 & $57.43 \pm 0.66 b c$ & $38.72 \pm 0.86 \mathrm{~d}$ & $7.63 \pm 0.42 \mathrm{e}$ & $11.15 \pm 0.63 \mathrm{e}$ & $39.47 \pm 0.85 \mathrm{fg}$ \\
\hline \multirow[t]{3}{*}{ MD } & 3 & $52.83 \pm 0.27 \mathrm{ef}$ & $41.11 \pm 0.09 \mathrm{bc}$ & $12.49 \pm 0.11 \mathrm{c}$ & $16.90 \pm 0.16 b$ & $42.97 \pm 0.08 b \mathrm{c}$ \\
\hline & 5 & $56.74 \pm 0.68 \mathrm{bcd}$ & $39.16 \pm 0.20 \mathrm{~d}$ & $10.52 \pm 0.18 \mathrm{~d}$ & $15.04 \pm 0.17 \mathrm{c}$ & $40.55 \pm 0.24 \mathrm{ef}$ \\
\hline & 10 & $61.86 \pm 1.00 \mathrm{a}$ & $36.55 \pm 0.59 \mathrm{e}$ & $8.11 \pm 0.17 \mathrm{e}$ & $12.51 \pm 0.07 \mathrm{de}$ & $37.43 \pm 0.60 \mathrm{~h}$ \\
\hline \multirow[t]{3}{*}{ MD:GA } & 3 & $47.45 \pm 0.98 \mathrm{~g}$ & $41.83 \pm 0.23 \mathrm{ab}$ & $14.76 \pm 1.06 \mathrm{~b}$ & $19.43 \pm 1.36 \mathrm{a}$ & $44.37 \pm 0.26 \mathrm{ab}$ \\
\hline & 5 & $50.75 \pm 0.59 \mathrm{f}$ & $40.97 \pm 0.22 b c$ & $12.50 \pm 0.34 \mathrm{c}$ & $16.96 \pm 0.36 \mathrm{~b}$ & $42.83 \pm 0.30 \mathrm{c}$ \\
\hline & 10 & $59.05 \pm 0.82 \mathrm{ab}$ & $37.03 \pm 0.36 \mathrm{e}$ & $8.42 \pm 0.15 \mathrm{e}$ & $12.81 \pm 0.10 \mathrm{~d}$ & $37.97 \pm 0.39 \mathrm{gh}$ \\
\hline \multicolumn{7}{|c|}{ Powder in solution } \\
\hline RE & 0 & $68.32 \pm 0.24 \mathrm{e}$ & $35.18 \pm 0.46 \mathrm{a}$ & $14.29 \pm 0.08 \mathrm{a}$ & $22.10 \pm 0.15 \mathrm{a}$ & $37.97 \pm 0.46 a$ \\
\hline \multirow[t]{3}{*}{ GA } & 3 & $71.86 \pm 0.75 \mathrm{~d}$ & $31.12 \pm 0.78 \mathrm{~b}$ & $11.65 \pm 0.26 b c$ & $20.53 \pm 0.31 \mathrm{ab}$ & $33.24 \pm 0.80 \mathrm{~b}$ \\
\hline & 5 & $74.71 \pm 2.29 b c$ & $29.97 \pm 1.27 \mathrm{bc}$ & $11.13 \pm 1.00 \mathrm{~cd}$ & $20.34 \pm 0.98 \mathrm{ab}$ & $31.97 \pm 1.52 \mathrm{bc}$ \\
\hline & 10 & $79.63 \pm 0.80 \mathrm{a}$ & $23.57 \pm 0.67 \mathrm{e}$ & $8.89 \pm 0.41 \mathrm{e}$ & $20.66 \pm 1.06 a b$ & $25.19 \pm 0.64 \mathrm{e}$ \\
\hline \multirow[t]{3}{*}{ MD } & 3 & $72.11 \pm 0.71 \mathrm{~cd}$ & $30.19 \pm 0.52 b$ & $11.98 \pm 0.23 b c$ & $21.64 \pm 0.08 \mathrm{a}$ & $32.48 \pm 0.57 b$ \\
\hline & 5 & $76.19 \pm 0.88 b$ & $26.80 \pm 0.60 \mathrm{~d}$ & $10.10 \pm 0.17 \mathrm{~d}$ & $20.65 \pm 0.12 \mathrm{ab}$ & $28.65 \pm 0.62 d$ \\
\hline & 10 & $80.01 \pm 0.22 \mathrm{a}$ & $22.22 \pm 0.62 \mathrm{ef}$ & $7.95 \pm 0.13 \mathrm{e}$ & $19.68 \pm 0.25 b$ & $23.60 \pm 0.63 \mathrm{ef}$ \\
\hline \multirow[t]{3}{*}{ MD:GA } & 3 & $72.59 \pm 0.60 \mathrm{~cd}$ & $31.38 \pm 0.41 \mathrm{~b}$ & $12.58 \pm 0.27 b$ & $21.85 \pm 0.17 \mathrm{a}$ & $33.81 \pm 0.48 b$ \\
\hline & 5 & $75.63 \pm 0.27 \mathrm{~b}$ & $28.14 \pm 0.41 \mathrm{~cd}$ & $11.21 \pm 0.20 \mathrm{~cd}$ & $21.73 \pm 0.47 \mathrm{a}$ & $30.29 \pm 0.38 \mathrm{~cd}$ \\
\hline & 10 & $80.44 \pm 0.83 \mathrm{a}$ & $21.23 \pm 0.73 \mathrm{f}$ & $8.49 \pm 0.25 \mathrm{e}$ & $21.81 \pm 1.11 \mathrm{a}$ & $22.87 \pm 0.63 \mathrm{f}$ \\
\hline
\end{tabular}

${ }^{\mathrm{a}}$ Different letters in the same column indicate significant differences $(\mathrm{p} \leq 0.05)$ between values. GC, gum concentration; RE, Roselle extract; GA, gum arabic; MD, maltodextrin.

Green-red color $\left(a^{*}\right)$. Green-red color values $\left(a^{*}\right)$ decreased significantly, as gum concertation increased, with averages of $39.72 \pm 1.07,38.94 \pm 2.01,39.94 \pm 2.23$ for RPs with GA, MD, and MD:GA, respectively. RE RPs had the highest red color value $(42.68 \pm 0.26)$. The average green-red color values by gum concentration were $42.68 \pm 0.26,41.20 \pm 0.55,39.97 \pm 0.94$, and $37.43 \pm 1.13$ for $0,3,5$, and $10 \%$ gums.

Yellow-blue color $(b *)$. Yellow-blue color values $(b *)$ were significantly different among different concentrations and types of gum. The overall averages were $9.70 \pm 1.66,10.38 \pm 1.91$, and $11.89 \pm 2.84$ for RPs with GA, MD, and MD:GA, respectively. RE RPs had the highest $b^{*}$ value $(16.31 \pm 0.25)$. An increase in gum concertation was associated with a decrease in $b^{*}$ values, with values of $16.31 \pm 0.25,12.81 \pm 1.67,11.11 \pm 1.11$, and $8.05 \pm 0.42$ for $0,3,5$, and $10 \%$ gums, respectively.

Hue $(H)$. RE RPs had a higher $H$ value $\left(20.92 \pm 0.40^{\circ}\right)$ than RPs with GA $\left(13.68 \pm 1.99^{\circ}\right)$, MD $\left(14.82 \pm 1.91^{\circ}\right)$, or MD:GA $\left(16.40 \pm 2.98^{\circ}\right)$. These differences among gum types were significant. $H$ values were also associated with gum concentrations: as gum concentrations decreased, $H$ values increased $\left(20.92 \pm 0.40^{\circ}, 17.23 \pm 1.92^{\circ}\right.$, $15.51 \pm 1.16^{\circ}$, and $12.16 \pm 0.83^{\circ}$ for RPs with gum concentrations of $0,3,5$, and $10 \%$, respectively). Hue values are located in the red-yellow segment $\left(0-90^{\circ}\right)$ of the color space; however, these values tend to lie in the deep red or purple color areas (McLaren, 1986).

Purity $(C)$. The purity (chroma) of all RPs showed trends that were similar to those of hue. Significant differences were observed based on type of gum added, with purities of RPs with GA, MD, and MD:GA of 40.91 $\pm 1.38,40.32 \pm 2.43$, and $41.72 \pm 2.90$, respectively. RE RPs were purer ( $45.69 \pm 0.17)$ than RPs with GA, MD, or MD:GA. The purity of powders were found to decrease as gum concentration increased, with purity values of $45.69 \pm 0.17,43.17 \pm 0.99,41.49 \pm 1.18$, and $38.29 \pm 1.07$ with gum concentrations of $0,3,5$, and $10 \%$, respectively. RE RPs showed the highest purity ( $\leq 0.05$ ). Purity values specify the position of colors between gray and a pure hue (saturation). Therefore, the purity or chroma of a color is proportional to the amount of color it has (McLaren, 1986). Figure 4 illustrates the correlation between $a^{*}$ and purity values for all treatments; an increase in the $a^{*}$ value was associated with an increase hue purity. 


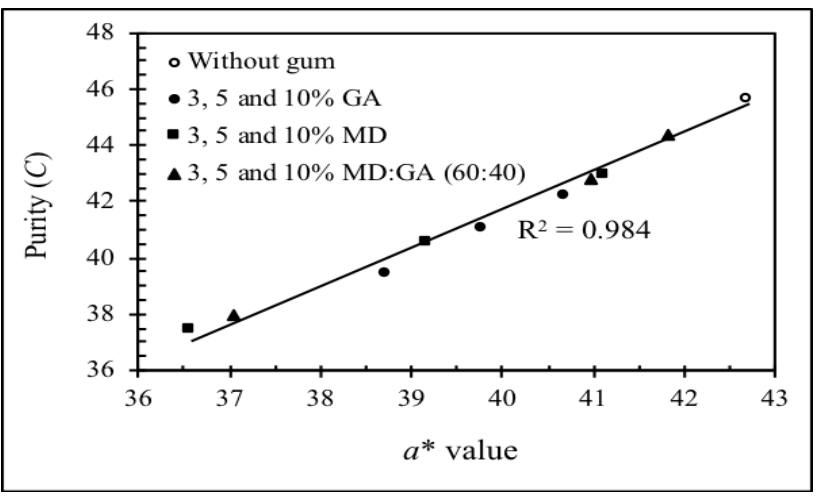

Figure 4. Correlation between purity and green-red color values for microencapsulated Roselle calyces powders with different gums

\subsubsection{Color of Powders in Solution}

Table 5 shows the color parameters for RPs in solution. Significant differences $(\mathrm{p} \leq 0.05)$ were observed between RPs with different types and concentrations of gums. $L^{*}, a^{*}$, and $b^{*}$ color parameters and purity of RPs in solution were similar to those for dry RPs. The lightness $\left(L^{*}\right)$ of powders in solution was higher (68-80) than that of powders because the solutions were dark red-purple but transparent. The RE RPs in solution were the darkest of all solutions. The red color $\left(a^{*}\right)$ of solutions decreased as gum concentration increased. The $b^{*}$ (yellow) color values for solutions were also similar to those for powders. The purity of solutions was less than those for the powders (23-38). Purities of solutions with RE (22.10 \pm 0.15$)$ and MD:GA (21.79 \pm 0.61$)$ RPs were significantly different $(\mathrm{p} \leq 0.05)$ from those of solutions with GA $(20.51 \pm 0.75)$ and MD $(20.66 \pm 0.86)$ RPs. Significant differences $(\mathrm{p} \leq 0.05)$ were also observed between RP solutions with $0,3,5$, and $10 \%$ gum. Ochoa-Velasco et al. (2017) evaluated the color values for reconstituted RPs (100 mg/7.5 mL of distilled water) encapsulated with mesquite gum at different concentrations. The average $L, a$, and $b$ color value ranges were $23.96 \pm 0.66-30.54 \pm 0.05,32.83 \pm 3.83-40.37 \pm 0.39$, and $14.56 \pm 1.77-18.66 \pm 0.08$, respectively. These results differ from those reported in this work, possibly because of the difference in gum type, as well as solution concentration.

\subsubsection{Antioxidant Characteristics}

Table 6 shows TMAs, TPCs, and AC for the different RPs.

TMAs. The TMA contents in GA (476.39 $\pm 64.18 \mathrm{mg} / 100 \mathrm{~g}), \mathrm{MD}(437.38 \pm 79.55 \mathrm{mg} / 100 \mathrm{~g})$, and MD:GA $(450.10 \pm 91.38 \mathrm{mg} / 100 \mathrm{~g}$ powder) RPs were significantly different. RE RPs had higher $(\mathrm{p} \leq 0.05)$ TMA content $(665.39 \pm 9.34 \mathrm{mg} / 100 \mathrm{~g})$ than the other RPs. As gum concentration increased, TMA content decreased: 3\% RPs showed higher TMA content than 5 and 10\% RPs, with values of 531.62 $\pm 14.22,477.10 \pm$ 35.22 , and $355.15 \pm 30.05 \mathrm{mg}$ cyanidin-3-glucoside equivalents $/ 100 \mathrm{~g}$ of powder for 3,5 , and $10 \%$ gums, respectively.

TPCs. The TPC content in GA $(2827.9 \pm 364.8 \mathrm{mg} / 100 \mathrm{~g}), \mathrm{MD}(499.4 \pm 2956.1 \mathrm{mg} / 100 \mathrm{~g})$, and MD:GA $(3160.1 \pm 549.4 \mathrm{mg} / 100 \mathrm{~g}$ of powder) RPs were significantly different. RE RPs had the highest ( $\mathrm{p} \leq 0.05) \mathrm{TPC}$ content ( $4929.4 \pm 175.4 \mathrm{mg} / 100 \mathrm{~g})$. As the gum concentration increased, TPC content decreased: RPs with $3 \%$ gum showed higher TPC content than RPs with 5 and $10 \%$ of gum, with values of $3472.9 \pm 329.5,167.3 \pm$ 3046.2 , and $2424.9 \pm 138.0 \mathrm{mg} / 100 \mathrm{~g}$ of powder for 3, 5, and $10 \%$ gums, respectively.

$A C$. No significant differences ( $\mathrm{p}>0.05$ ) were observed between the ACs of RE $(1284.9 \pm 20.8 \mathrm{mg} / 100 \mathrm{~g})$, GA $(1275.3 \pm 185.2 \mathrm{mg} / 100 \mathrm{~g}), \mathrm{MD}(1187.2 \pm 146.4 \mathrm{mg} / 100 \mathrm{~g})$, and MD:GA $(1186.3 \pm 102.9 \mathrm{mg}$ TE$/ 100 \mathrm{~g}$ of powder) RPs. Regarding gums concentration, RPs with 5\% gum showed higher antioxidant capacity (1382.2 \pm $106.0 \mathrm{mg}$ ET/100 g powder) than RPs with $3 \%(1186.0 \pm 94.5 \mathrm{mg} / 100 \mathrm{~g})$ and $10 \%(1080.5 \pm 45.5 \mathrm{mg} / 100 \mathrm{~g}$ powder) gum. 
Table 6. Effect of gum type and concentration on the antioxidant properties of spray-dried powders ${ }^{\mathrm{a}}$

\begin{tabular}{lllll}
\hline Gum type & $\mathrm{GC}(\% \mathrm{w} / \mathrm{w})$ & $\mathrm{TMAs}^{\mathrm{b}}$ & \multicolumn{3}{c}{$\mathrm{TPCs}^{\mathrm{c}}$} & \multicolumn{3}{c}{$\mathrm{AC}^{\mathrm{d}}$} \\
\cline { 3 - 5 } & & $665.39 \pm 9.34 \mathrm{a}$ & $400 \mathrm{~g}$ of dry powder $)$ \\
\hline $\mathrm{RE}$ & 0 & $525.37 \pm 19.34 \mathrm{~b}$ & $3090.2 \pm 175.4 \mathrm{a}$ & $1284.9 \pm 20.8 \mathrm{bc}$ \\
$\mathrm{GA}$ & 3 & $510.33 \pm 32.46 \mathrm{bc}$ & $3036.5 \pm 161.3 \mathrm{~d}$ & $1226.9 \pm 115.5 \mathrm{bcd}$ \\
& 5 & $393.45 \pm 7.72 \mathrm{e}$ & $2357.0 \pm 92.4 \mathrm{e}$ & $1100.6 \pm 46.0 \mathrm{a}$ \\
& 10 & $530.30 \pm 4.46 \mathrm{~b}$ & $3527.0 \pm 165.6 \mathrm{bc}$ & $1120.7 \pm 95.1 \mathrm{~cd}$ \\
$\mathrm{MD}$ & 3 & $440.20 \pm 9.98 \mathrm{~b}$ & $2950.8 \pm 181.0 \mathrm{~d}$ & $1368.2 \pm 17.3 \mathrm{ab}$ \\
& 5 & $341.65 \pm 5.29 \mathrm{f}$ & $2390.4 \pm 111.6 \mathrm{e}$ & $1072.6 \pm 56.2 \mathrm{~b}$ \\
& 10 & $539.19 \pm 13.27 \mathrm{~b}$ & $3801.6 \pm 125.9 \mathrm{~b}$ & $1210.4 \pm 11.7 \mathrm{bcd}$ \\
MD:GA & 3 & $480.76 \pm 9.37 \mathrm{~cd}$ & $3151.3 \pm 110.1 \mathrm{~cd}$ & $1280.0 \pm 83.5 \mathrm{bc}$ \\
& 5 & $330.35 \pm 16.29 \mathrm{f}$ & $2527.5 \pm 155.5 \mathrm{e}$ & $1068.5 \pm 31.7 \mathrm{~d}$ \\
\hline
\end{tabular}

${ }^{\mathrm{a}}$ Different letters in the same column indicate significant differences $(\mathrm{p} \leq 0.05)$ between values. ${ }^{\mathrm{b}}$ TMAs: total monomeric anthocyanins (cyanidin-3-glucoside equivalents). ${ }^{\mathrm{c}} \mathrm{TPC}$ : total phenolic compounds (gallic acid equivalents). ${ }^{\mathrm{d}} \mathrm{AC}$ : Antioxidant activity (Trolox equivalents). GC, gum concentration; RE, Roselle extract; GA, gum arabic; MD, maltodextrin.

\section{Conclusions}

Based on the drying conditions used in this study, the microencapsulated RPs obtained with a mixture of MD and GA (60:40) as a carrier were the preferred powders because of its higher yields and better antioxidant and color characteristics. However, the red color $\left(a^{*}\right)$ average for all powders decreased as the gum concentration increased which is due to the gum concentration. In addition, the 3\% MD:GA RP showed the highest amount of TMAs (cyaniding-3-glucoside equivalents/100 g) and TPCs; however, TMAs and TPCs were well maintained in all MD:GA RPs. These results indicate that microencapsulated powders can be used successfully to produce attractive functional foods as well as imparting flavor characteristics to foods. However, a stability study should be conducted with these RPs to evaluate their carrier efficiency. A study of MD:GA mixtures at different ratios than those used in this work should also be conducted to optimize yields and physicochemical properties of RPs obtained. Therefore, more studies about stability of color, solubility, moisture sorption characteristics, and maintenance of antioxidant properties are required.

\section{Acknowledgments}

Sandro Cid-Ortega thanks PRODEP (Program for Educational Professional Improvement) and UTIM (Universidad Tecnológica de Izúcar Matamoros, Puebla, Mexico) for the scholarship granted to complete his doctoral studies.

\section{References}

Andrade, I., \& Flores, H. (2004). Optimization of spray drying of Roselle extract (Hibiscus sabdariffa L.). In Proceedings of the 14th International Drying Symposium, São Paulo, Brazil. pp. 597-604.

AOAC. (1995). Official Methods of Analysis. Association of Official Analytical Chemists. Inc. (14th ed.). Washington, D.C., USA.

AOAC. (2000). Official Methods of Analysis of AOAC International. Association of Official Analytical Chemists. Inc. (17th ed.). Maryland, USA.

Brand-Williams, W., Cuvelier M. E., \& Berset C. (1995). Use of a free radical method to evaluate antioxidant activity. Lebensmittel-Wissenschaft und-Technologie, 28, 25-30. https://doi.org/10.1016/S0023-6438(95)80008-5

Cannon Instrument Company. (2000). Certificate of calibration. Cannon-Fenske routine type for transparent liquids (standard test ASTM D 445, IP 71 and ISO 3104). State College, PA, USA.

Cannon Instrument Company. (2014). Calculation of viscometer constants for Cannon-Fenske Routine and Cannon-Fenske Opaque Viscometers. State College, PA, USA. Retrieved from https://www.cannoninstrument.com/TechBrief101.pdf

Cid-Ortega, S., \& Guerrero-Beltrán, J. A. (2014). Roselle calyces particle size effect on the physicochemical and phytochemicals characteristics. Journal of Food Research, 3(5), 83-94. 
http://dx.doi.org/10.5539/jfr.v3n5p83

Cissé, M., Vaillant, F., Acosta, O., Dhuique-Mayer, C. Y., \& Dornier, M. (2009). Thermal degradation kinetics of anthocyanins from blood orange, blackberry, and Roselle using the Arrhenius, Eyring, and Ball models. Journal of Agricultural and Food Chemistry, 57(14), 6285-6291. http://dx.doi.org/10.1021/jf900836b

Ersus, S., \& Yurdagel, U. (2007). Microencapsulation of anthocyanin pigments of black carrot (Daucus carota L.) by spray drier. Journal of Food Engineering, 80, 805-812. https://doi.org/10.1016/j.jfoodeng.2006.07.009

Esmaeili, A. K., Taha, R., Mohajer, S., \& Banisalam, B. (2015). Antioxidant activity and total phenolic and flavonoid content of various solvent extracts from In Vivo and In Vitro grown Trifolium pratense L. (red clover). BioMed Research International, 2015, 11. http://dx.doi.org/10.1155/2015/643285

Farimin, A. O. A., \& Nordin, E. (2009). Physical properties of powdered Roselle-pineapple juice-effects of maltodextrin. In M. M. Noor, M. M. Rahman, \& K. Kadirgama (Eds.), National Conference on Postgraduate Research (NCON-PGR) (pp. 90-97). University Malaysia Pahang.

Fazaeli, M., Emam-Djomeh, Z., Ashtari, A. K., \& Omid, M. (2012). Effect of spray drying conditions and feed composition on the physical properties of black mulberry juice powder. Food and Bioproducts Processing, 90, 667-675. https://doi.org/10.1016/j.fbp.2012.04.006

Fennema, O. R. (1985). Water and ice. In O. R. Fennema (Ed.), Food Chemistry (2nd ed., pp. 23-67). Marcel Dekker, Inc., NY, NY, USA.

Gharsallaoui, A., Roudaut, G., Chambin, O., Voilley, A., \& Saurel, R. (2007). Applications of spray-drying in microencapsulation of food ingredients: An overview. Food Research International, 40, 1107-1121. https://doi.org/10.1016/j.foodres.2007.07.004

Gonzales-Palomares, S., Estarrón-Espinosa, M., Gómez-Leyva, J. F., \& Andrade-González, I. (2009). Effect of the temperature on the spray drying of Roselle extracts (Hibiscus sabdariffa L.). Plant Foods for Human Nutrition, 64, 62-67. https://doi.org/10.1007/s11130-008-0103-y

Idham, Z., Muhamad, I. I., \& Sarmidi, M. R. (2012). Degradation kinetics and color stability of spray-dried encapsulated anthocyanins from Hibiscus sabdariffa L. Journal of Food Process Engineering, 35, 522-542. https://doi.org/10.1111/j.1745-4530.2010.00605.x

Jumah, R. Y., Tashtoush, B., Shaker, R. R., \& Zraiy, A. F. (2000). Manufacturing parameters and quality characteristics of spray dried jameed. Drying Technology, 18(4 and 5), 967-984. https://doi.org/10.1080/07373930008917747

Kolanowski, W., Ziolkowski, M., Weißbrodt, J., Kunz, B., \& Laufenberg, G. (2006). Microencapsulation of fish oil by spray drying-impact on oxidative stability. Part 1. European Food Research Technology, 222, 336-342. https://doi.org/10.1007/s00217-005-0111-1

Langrish, T., \& Chiou, D. (2008a). Producing powders of hibiscus extract in a laboratory-scale spray dryer. International Journal of Food Engineering, 11, 1-21. https://doi.org/10.2202/1556-3758.1411

Langrish, T., \& Chiou, D. (2008b). Stabilization of moisture sorption in spray-dried bioactive compounds by using novel fibre carriers to crystallize the powders. International Journal of Food Engineering, 12, 1-7. https://doi.org/10.2202/1556-3758.1359

Lee, J., Durst, R. W., \& Wrolstad, R. E. (2005). Total monomeric anthocyanin pigment content of fruit juices, beverages, natural colorants, and wines by the $\mathrm{pH}$ differential method: collaborative study. Journal of AOAC International, 88(5), 1269-1278. https://doi.org/10.1093/jaoac/88.5.1269

Lopez, M. B. E., Carvajal, de P. L. M., \& Millan, C. L. de J. (2009). Establecimiento de condiciones de la mezcla de pulpa de banano (Musa paradisiaca L.) para someter a secado por aspersión. VITAE, Revista de la Facultad de Química Farmacéutica (Universidad de Antioquia, Medellín, Colombia), 16(3), 287-296.

McLaren, K. (1986). Colour measuring instruments. In The Colour Science of Dyes and Pigments (pp. 116-128), Adam Higher Ltd., Great Britain.

Molyneux, P. (2004). The use of the stable free radical diphenylpicrylhydrazyl (DPPH) for estimating antioxidant activity. Songklanakarin Journal of Science and Technology, 26, 211-219.

Munin, A., \& Edwards-Lévy, F. (2011). Encapsulation of natural polyphenolic compounds; a review. Pharmaceutics, 3, 793-829. https://doi.org/10.3390/pharmaceutics3040793

NOM. (2001). NOM-104-STPS. Norma Oficial Mexicana, Agentes extinguidores-Polvo químico seco tipo ABC 
a base de fosfato mono amónico. Secretaria del Trabajo y Previsión Social, México, Distrito Federal.

O’Hagan, P., Hasapidis, K., Coder, A., Helsing, H., \& Pokrajac, G. (2005). Particle size analysis of food powders. In C. Onwulata (Ed.), Encapsulated and Powdered Foods (pp. 215-245). CRC Press Taylor \& Francis Group, Boca Raton, FL, USA. https://doi.org/10.1201/9781420028300.pt3

Ochoa-Velasco, C. E., Salazar-González, C., Cid-Ortega, S., \& Guerrero-Beltrán, J. A. (2017). Antioxidant characteristics of extracts of Hibiscus sabdariffa calyces with mesquite gum. Journal of Food Science and Technology, 54(7), 1747-1756. https://doi.org/10.1007/s13197-017-2564-1

Peng-Kong, W., Yusof, S., Ghazali, H. M., \& Che-Man, Y. B. (2002). Physico-chemical characteristics of Roselle (Hibiscus sabdariffa L.). Nutrition and Food Science, 32(2), 68-73. https://doi.org/10.1108/00346650210416994

Salazar-González, C., Vergara-Balderas, F. T., Ortega-Regules, E., \& Guerrero-Beltrán, J. A. (2012). Antioxidant properties and color of Hibiscus sabdariffa extracts. Ciencia e Investigación Agraria, 39(1), 79-90. http://doi.org/10.4067/S0718-16202012000100006

Santos, D. T., \& Meireles, M. A. (2010). Carotenoid pigments encapsulation: fundamentals, techniques and recent trends. The Open Chemical Engineering Journal, 4, 42-50. http://doi.org/10.2174/1874123101004010042

Selim, K. A., Khalil, K. E., Abdel-Bary, M. S., \& Abdel-Azeim, N. A. (2008). Extraction, encapsulation and utilization of red pigments from Roselle (Hibiscus sabdariffa L.) as natural food colourants. Alexandria Journal of Food Science and Technology (Alexandria University, Alexandria, Egypt), Special Volume Conference, pp. 7-20. http://doi.org/10.12816/ajfs.2008.19642

Silva, P. I., Stringheta, P. C., Teófilo, R. F., \& Nolasco de Oliveira, I. R. (2013). Parameter optimization for spray-drying microencapsulation of jaboticaba (Myrciaria jaboticaba) peel extracts using simultaneous analysis of responses. Journal of Food Engineering, 117(4), 538-544.

https://doi.org/10.1016/j.jfoodeng.2012.08.039

Singleton, V. L., \& Rossi, J. A. (1965). Colorimetry of total phenolics with phosphomolybdic-phosphotungstic acid reagents. American Journal of Enology and Viticulture, 16(3), 144-158.

Tonon, R. V., Freitas, S. S., \& Hubinger, M. D. (2011). Spray drying of açai (Euterpe oleraceae Mart.) juice: effect of inlet air temperature and type of carrier agent. Journal of Food Processing and Preservation, 35, 691-700. https://doi.org/10.1111/j.1745-4549.2011.00518.x

Vega, C., \& Roos, Y. H. (2006). Invited review: spray-dried dairy and dairy-like emulsions-compositional considerations. Journal of Dairy Science, 89(2), 383-401. https://doi.org/10.3168/jds.S0022-0302(06)72103-8

Wijaya, M., Small, D. M., \& Bui, L. (2011). Microencapsulation of ascorbic acid for enhanced long-term retention during storage. Human Protection and Performance Division. Defence Science and Technology Organisation (DSTO), Fisherman's Bend, Victoria, Australia. pp. 43.

Zhang, L., Mou, D., \& Du, Y. (2007). Procyanidins: Extraction and microencapsulation. Journal of the Science of Food and Agriculture, 87, 2192-2197. https://doi.org/10.1002/jsfa.2899

\section{Copyrights}

Copyright for this article is retained by the author(s), with first publication rights granted to the journal.

This is an open-access article distributed under the terms and conditions of the Creative Commons Attribution license (http://creativecommons.org/licenses/by/4.0/). 